\title{
ANALISIS KESESUAIAN ISI BUKU TEMATIK KELAS IV SEKOLAH DASAR DENGAN PENDIDIKAN KARAKTER, DAN PENDEKATAN SCIENTIFIC
}

\author{
Ruminiati \\ Khusubakti Andajani \\ Program Studi Pendidikan Guru Sekolah Dasar-FIP, Universitas Negeri Malang \\ Jln. Semarang 5 Malang \\ E-mail: ruminiati@gmail.com
}

\begin{abstract}
This study is designed to analyse the content of thematically integrated textbook for students at fourth-grade primary schools with character building and scientific approach. The study is descriptive qualitative study. The result of the study showed that generally, the materials within the book have been developed in accordance with character building and thematic approach. However, there was some discordance within the thematic textbook that were suggested by the government, especially in character building and scientific approach aspects. In summary, the textbook for students at fourth-grade primary school which is published by the Ministry of Education and Culture does not fully contain character building and scientific approach.
\end{abstract}

Keywords: primary school, thematic textbook, character building, scientific approach, 2013 Curriculum.

\begin{abstract}
Abstrak: Penelitian ini bertujuan untuk menganalisis isi buku tematik siswa kelas IV SD dengan pendekatan pendidikan karakter dan scientific. Rancangan dalam penelitian ini adalah deskriptif kualitatif. Temuan penelitian menunjukkan bahwa secara umum materi dalam buku tersebut telah dikembangkan dengan memperhatikan aspek pendidikan karakter dan pendekatan scientific. Namun, di beberapa bagian terdapat sejumlah ketidaksesuaian buku tematik siswa yang telah diamanatkan Kurikulum 2013, khususnya dalam aspek pendidikan karakter dan pendekatan scientific. Kesimpulannya, buku siswa kelas IV SD yang diterbitkan Kemendikbud berdasarkan Kurikulum 2013 belum seluruhnya benar dari pendidikan karakter dan pendekatan scientific.
\end{abstract}

Kata kunci: buku tematik siswa SD, pendidikan karakter, scientific, Kurikulum 2013.

Pengembangan Kurikulum 2013 dilaksanakan atas dasar beberapa prinsip diantaranya Pertama, standar kompetensi lulusan diturunkan dari kebutuhan. Kedua, standar isi diturunkan dari standar kompetensi lulusan melalui kompetensi inti yang bebas mata pelajaran. Ketiga, semua mata pelajaran harus berkontribusi terhadap pembentukan sikap, keterampilan, dan pengetahuan peserta didik. Keempat, mata pelajaran diturunkan dari kompetensi yang ingin dicapai. Kelima, semua mata pelajaran diikat oleh kompetensi inti. Keenam, keselarasan tuntutan kompetensi lulusan, isi, proses pembelajaran, dan penilaian. Aplikasi yang taat asas dari prinsip-prinsip ini menjadi sangat esensial dalam mewujudkan keberhasilan implementasi Kurikulum 2013 (Kemendikbud, 2013b).

Demi tercapainya tujuan pendidikan nasional di atas perlu dilakukan berbagai upaya formal untuk mewujudkan watak dan budi pekerti generasi muda bangsa yang berkarakter. Melihat kondisi umum bangsa Indonesia saat ini, banyak terjadi 
krisis moral diseluruh lapisan masyarakat dalam berbagai bentuk dan rupa. Ini membuktikan bahwa tujuan pendidikan nasional tersebut belum tercapai. Pendidikan yang diselenggarakan selama ini terbukti cenderung belum mampu menghasilkan peserta didik yang berkarakter, sehingga perlu ditingkatkan lagi. Hal ini, sejalan dengan pendapat Judiani, (2010) bahwa pendidikan di Indonesia masih terfokus pada aspek-aspek kognitif atau akademik, sedangkan aspek softskills atau nonakademik masih kurang mendapatkan perhatian.

Dalam Undang-Undang nomor 20 Tahun 2003 tentang Sistem Pendidikan Nasional dijelaskan bahwa pendidikan nasional didasarkan pada Pancasila dan Undang-Undang Dasar Negara Republik Indonesia Tahun 1945. Lebih lanjut dijelaskan bahwa pendidikan nasional berfungsi untuk mengembangkan kemampuan dan membentuk watak serta peradaban bangsa yang bermartabat dalam rangka mencerdaskan kehidupan bangsa. Pendidikan nasional bertujuan untuk mengembangkan potensi peserta didik agar menjadi manusia yang beriman dan bertakwa kepada Tuhan Yang Maha Esa, berakhlak mulia, sehat, berilmu, cakap, kreatif, mandiri, dan menjadi warga negara yang demokratis serta bertanggung jawab (Kemendikbud, 2013a).

Perlu diketahui bahwa terdapat sejumlah pendapat yang berbeda dalam upaya penerapan pendidikan karakter bangsa di sekolah. Pertama, pendidikan karakter diberikan berdiri sendiri sebagai suatu mata pelajaran. Kedua, pendidikan karakter diberikan secara terintegrasi dalam mata pelajaran PPKn, Pendidikan Agama, dan beberapa mata pelajaran lain yang relevan. Ketiga, pendidikan karakter diintergrasikan ke dalam seluruh mata pelajaran yang diajarkan kepada siswa. Pendapat pertama tampaknya tidak banyak diberlakukan di Indonesia. Pendapat kedua pernah diberlakukan dalam kurikulum pendidikan di Indonesia, yaitu pendidikan karakter menjadi tanggung jawab guru mata pelajaran PPKn dan Pendidikan Agama. Mulai Kurikulum 2006 diterapkan pendapat ketiga, yaitu pendidikan karakter diintegrasikan dalam seluruh mata pelajaran. Pendapat tersebut sejalan dengan pendapat Marzuki (2012) bahwa pengintegrasian pendidikan karakter dalam pembelajaran dapat dilakukan dengan pemuatan nilai-nilai karakter dalam semua mata pelajaran yang diajarkan di sekolah dan dalam pelaksanaan kegiatan pembelajaran.
Secara umum nilai-nilai karakter yang diamanatkan harus diinisiasikan dan diinternalisasikan kepada siswa SD meliputi (1) religius, (2) jujur, (3) toleransi, (4) disiplin, (5) kerja keras, (6) kreatif, (7) mandiri, (8) demokratis, (9) rasa ingin tahu, (10) semangat kebangsaan, (11) cinta tanah air, (12) menghargai prestasi, (13) bersahabat/komunikatif, (14) cinta damai, (15) gemar membaca, (16) peduli lingkungan, (17) peduli sosial, dan (18) tanggung jawab.

Dalam Kurikulum 2013 pendidikan karakter mendapat perhatian lebih. Belajar dari pengalaman, Kurikulum 2013 bertujuan mempersiapkan manusia Indonesia agar memiliki kemampuan hidup sebagai pribadi dan warga negara yang beriman, produktif, kreatif, inovatif, dan afektif, serta mampu berkontribusi pada kehidupan bermasyarakat, berbangsa, bernegara, dan peradaban dunia. Pengembangan kurikulum menjadi amat penting sejalan dengan kontinuitas kemajuan ilmu pengetahuan, teknologi, dan seni budaya serta perubahan masyarakat pada tataran lokal, nasional, regional, dan global di masa depan. Sebagaimana yang dikemukakan oleh Benninga et al, (2003) bahwa Sekolah dengan jumlah implementasi pendidikan karakter yang lebih tinggi cenderung memiliki nilai akademis yang lebih tinggi. Sehubungan dengan hal tersebut, pendidikan karakter menempati posisi penting dalam pendidikan nasional di Indonesia.

Kurikulum 2013 menekankan pada dimensi pedagogik modern dalam pembelajaran, yaitu menggunakan pendekatan scientific. Pendekatan scientific pada pembelajaran semua mata pelajaran meliputi mengamati, menanya, mencoba, menalar, dan membentuk jejaring. Mengamati dimaksudkan untuk menggali informasi melalui pengamatan. Menanya dimaksudkan untuk memenuhi rasa ingin tahu siswa melalui pertanyaan-pertanyaan yang diajukan kepada guru atau teman sejawat. Mencoba dimaksudkan untuk mengalami sesuatu yang dipelajari melalui percobaan, mengolah data atau informasi yang diperoleh berdasarkan pengetahuan baru yang diperoleh pada aktivitas sebelumnya, serta menyajikan data atau informasi. Menalar dimaksdukan untuk menganalisis dan merasionalkan pengetahuan baru yang diperolehnya dan mengaitkannya dengan kehidupan sehari-hari, menyimpulkan, dan jika meungkinkan mencipta. Selanjutnya siswa diminta mengomunikasikan hasil 
kerjanya kepada guru, teman sejawat, atau orang lain. Manfaat yang diperoleh guru dalam menggunakan pendekatan scientific dalam proses pembelajaran yaitu dengan adanya pendekatan saintifik siswa menjadi lebih aktif, kreatif, pembelajaran semakin lebih menyenangkan, siswa dapat berpikir lebih ilmiah dan karakter siswa semakin dibentuk (Paut, 2016).

Untuk mata pelajaran, materi, atau situasi tertentu, sangat mungkin pendekatan ilmiah ini tidak selalu tepat diaplikasikan secara prosedural. Pada kondisi seperti ini, tentu saja proses pembelajaran harus tetap menerapkan nilai-nilai atau sifat-sifat ilmiah dan menghindari nilai-nilai atau sifat-sifat nonilmiah.

Penilaian proses pembelajaran menggunakan pendekatan penilaian otentik (authentic assesment) yang menilai kesiapan siswa, proses, dan hasil belajar secara utuh. Keterpaduan penilaian ketiga komponen tersebut akan menggambarkan kapasitas, gaya, dan perolehan belajar siswa atau bahkan mampu menghasilkan dampak instruksional (instructional effect) dan dampak pengiring (nurturant effect) dari pembelajaran.

Buku siswa merupakan buku paket yang diterbitkan Kementerian Pendidikan dan Kebudayaan Indonesia dan diberikan secara gratis kepada seluruh siswa di Indonesia sesuai dengan jenjang kelas masing-masing. Buku ini dikembangkan berdasarkan pada KI dan KD yang terdapat dalam Kurikulum 2013, dan secara teoretis memperhatikan prinsip-prinsip dalam pendekatan scientific. Untuk jenjang SD, materi dikembangkan berbasis tematikterpadu. Buku siswa dikondisikan sebagai buku wajib yang harus digunakan/dikerjakan siswa pada setiap kegiatan pembelajaran.

Mengingat buku siswa dijadikan buku yang wajib digunakan siswa dalam pembelajaran, maka seharusnya buku tersebut disajikan dengan sebaik-baiknya dan sesempurna mungkin, Artinya penyajian materi dalam buku tersebut semestinya dimaksimalkan kualitasnya sehingga memudahkan guru dalam mencapai tujuan pendidikan nasional dan tujuan Kurikulum 2013.

Berdasarkan penelitian Sari, dkk, (2015) menunjukkan bahwa buku siswa yang dikembangkan dari aspek kelayakan isi berkategori "sangat baik", aspek kebahasaan berkategori "sangat baik", aspek penyajian berkategori "sangat baik", dan aspek kegrafikaan berkategori "sangat baik." Tidak sejalan dengan penelitian tersebtu, berdasarkan kajian awal yang dilakukan terhadap beberapa buku siswa ditemukan sejumlah catatan yang patut dikomentarkan pada buku siswa. Beberapa materi yang disajikan kurang menonjolkan muatan pendidikan karakter. Teknik penyajiannya pun cenderung tidak mendukung prosedur dalam pendekatan scientific yang diwajibkan dalam Kurikulum 2013. Nuansa dan pola lama masih dapat ditemui di beberapa bagian dalam buku tersebut, seperti langsung menyajikan materi tanpa memberi kesempatan kepada siswa untuk mengamati, menanya, menalar, dan mencoba. Beberapa penulis langsung menyebutkan isi materi (misal: definisi, jenis, contoh) tanpa memberi kesempatan kepada siswa untuk menempuh langkah-langkah dalam pendekatan scientific.

Berdasarkan latar belakang di muka, dilakukan analisis terhadap buku siswa jenjang sekolah dasar berdasarkan aspek pendidikan karakter dan pendekatan scientific. Keduanya merupakan aspek utama dalam Kurikulum 2013 yang sangat potensial dalam mewujudkan tujuan pengembangan Kurikulum 2013 dan tujuan pendidikan nasional. Kajian difokuskan pada Buku siswa kelas IV SD semester 1 untuk seluruh tema. Analisis ini urgen untuk dilakukan sebab penelitan hasil analisis ini dapat menginformasikan berbagai kelebihan dan kelemahan dalam buku siswa jejang SD dari aspek pendidikan karakter dan pendekatan scientific. Lebih lanjut, dapat digunakan juga sebagai bahan pertimbangan untuk menulis atau merevisi buku siswa edisi mendatang.

\section{METODE}

Penelitian ini merupakan penelitian kualitatif dengan jenis penelitian deskriptif. Dalam hal ini peneliti bermaksud memaparkan secara kualitatif kesesuaian sajian materi pada buku siswa kelas IV SD terbitan Kemendikbud dengan aspek pendidikan karakter dan pendekatan scientific sebagaimana yang diamanatkan dalam Kurikulum 2013.

Data dalam penelitian ini berupa informasi tentang kesesuaian sajian materi pada buku siswa dengan aspek pendidikan karakter dan pendekatan scientific. Sumber data dalam penelitian ini adalah buku siswa kelas IV SD yang diterbitkan oleh Kemendikbud (2013). Jumlah Buku siswa yang menjadi sumber data ada 9 buku, masing- 
masing mewakili tema-tema yang telah ditetapkan Kemendikbud dalam Kurikulum 2013.

Instrumen yang digunakan dalam penelitian ini adalah Pedoman Analisis Buku Siswa dan Lembar Kerja Analisis Buku Siswa sebagaimana indikatorindikator yang ditetapkan Kemendikbud untuk menguji kelayakan buku tersebut. Butir-butir aspek kajian difokuskan pada kesesuaian isi materi dalam Buku siswa kelas IV SD dengan muatan pendidikan karakter dan pendekatan scientific.

Data dalam penelitian ini dikumpulan dengan teknik dokumentasi. Berdasarkan isi buku siswa kelas IV SD diberikan penanda dan catatan singkat (note) pada bagian-bagian yang akan dianalisis, diikuti catatan sebagai interpretasi awal.

Analisis data dilakukan dengan terlebih dulu mencermati ulang data yang sudah ditandai untuk memastikan ketepatan interpretasi awal, kemudian membuat tabulasi data dan mengelompokkannya berdasarkan tujuan penelitian. Berdasarkan hasil tabulasi data tersebut selanjutnya dianalisis kesesuaian dan ketidaksesuaian sajian buku siswa dengan indikator yang telah ditetapkan. Berdasarkan hasil analisis ini, selanjutnya diusulkan perbaikan pada bab atau subbab yang tidak sesuai dengan indikator yang telah ditetapkan, sekaligus memberikan ulasan dan argumen terhadap setiap temuan yang diperoleh.

\section{HASIL}

Berikut disajikan hasil analisis terhadap kesesuaian sajian materi dalam buku siswa kelas IV SD dengan pendidikan karakter dan pendekatan scientfic.

\section{Aspek Pendidikan Karakter dalam Buku Siswa Kelas IV SD}

Sebagaimana disampaikan di muka, Kurikulum 2013 menekankan penanaman aspek sikap kepada diri siswa, baik sikap spiritual dan sosial. Dengan menggunakan acuan aspek pendidikan karakter yang digunakan untuk menganalisis kesesuaian isi buku tematik kelas IV SD, hasilnya sebagai berikut

Pada Subtema 1: Aku dan Cita-Citaku halaman 1-2 terdapat kegiatan siswa diminta untuk mencocokkan gambar dengan deskriptor di samping gambar tersebut. Pada kegiatan tersebut karakter mandiri dan rasa ingin tahu sudah tampak. Namun, karakter relegius dan menghargai prestasi belum

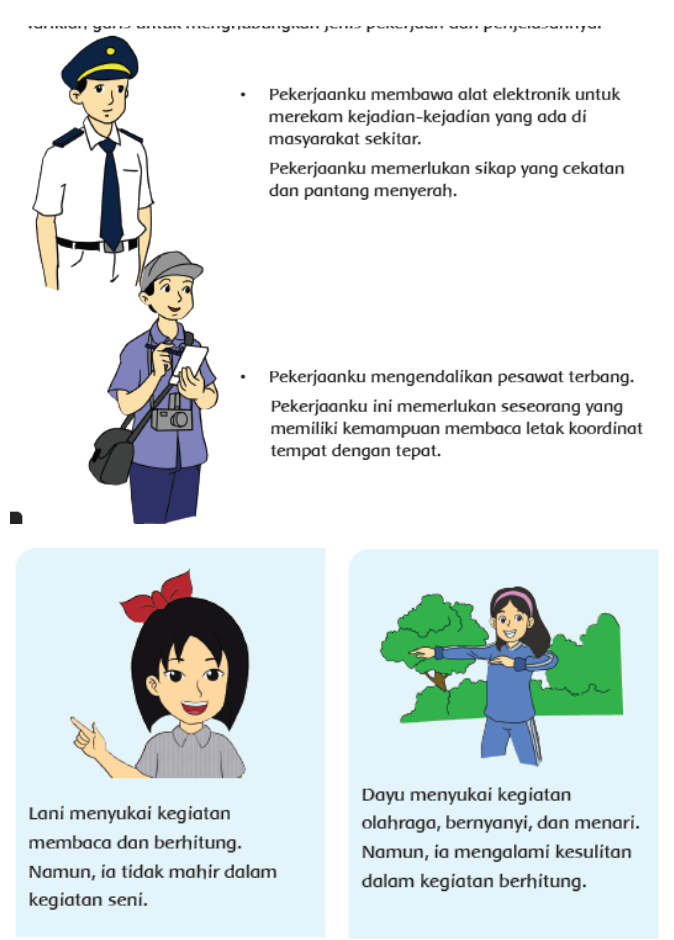

tampak. Sebaiknya karakter yang dimunculkan dalam kegiatan ini adalah relegius yaitu mensyukuri setiap cita-cita atau pekerjaan setiap orang. Karakter menghargai prestasi juga perlu dimunculkan agar siswa dapat menghargai cita-cita atau pekerjaan setiap orang.

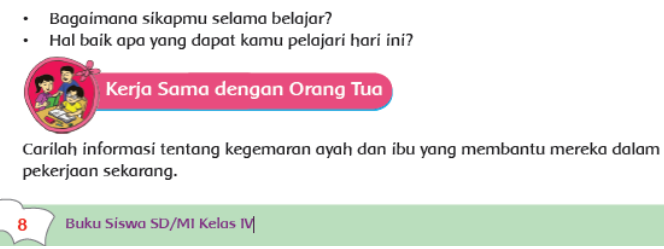

Pada Subtema 1: Aku dan Cita-Citaku halaman 5-6 kegiatan “Ayo Belajar” terdapat bacaan tentang kegemaran Lani dan Dayu. Berdasarkan bacaan terdapat pertanyaan yang memupuk karakter mandiri dan menghargai yang dimunculkan dalam pertanyaan tersebut. Namun. Karakter toleransi terhadap perbedaan kegemaran dalam bacaan belum tampak. Sebaiknya dalam bacaan juga dimunculkan karakter toleransi terhadap perbedaan kegemaran sehingga siswa mampu menjawab pertanyaan berkaitan dengan hal tersebut.

Pada Subtema 1: Aku dan Cita-Citaku halaman 8 terdapat kegiatan "Kerja sama Orang Tua" siswa diminta untuk mencari informasi tentang kegemaran ayah dan ibu yang membantu mereka dalam pekerjaan. Karakter yang muncul hanya rasa ingin tahu, namun karakter kerja keras belum tampak. 
Sebaiknya, kegiatan tersebut menyuruh siswa untuk mencari informasi tentang usah apa saja yang dilakukan oleh orang tuanya dalam mewujudkan cita-cita atau pekerjaannya. Sehingga karakter kerja keras tampak dalam kegiatan tersebut.

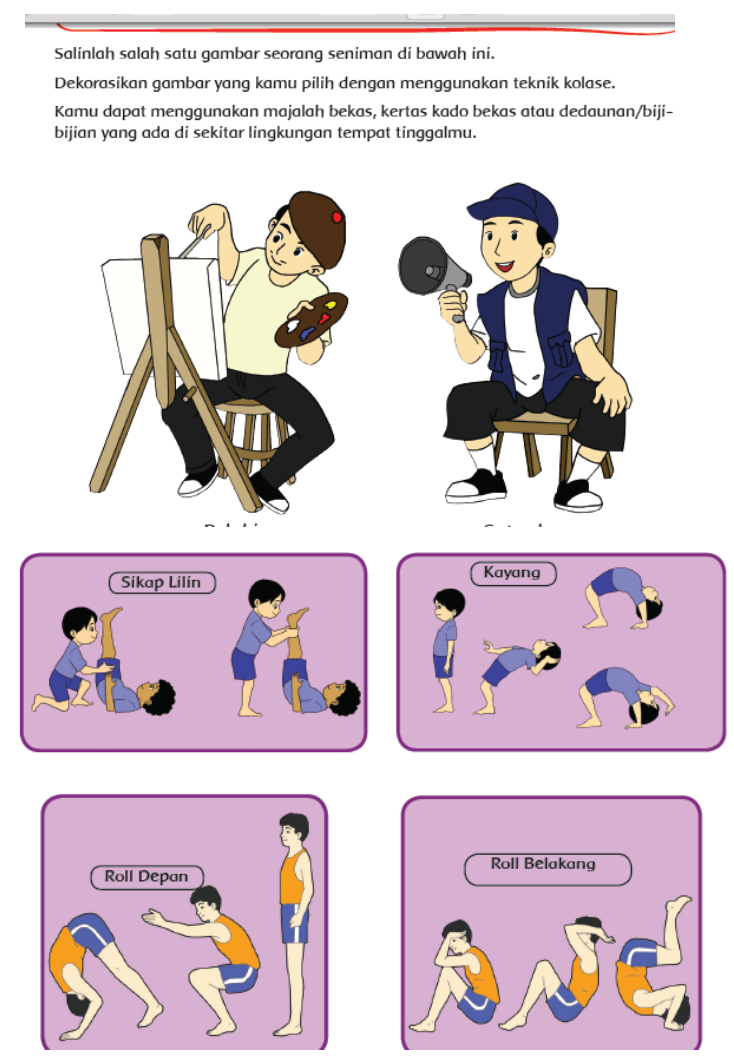

Pada Subtema 1: Aku dan Cita-Citaku halaman 11 terdapat kegiatan "Ayo Berkreasi" siswa diminta untuk menyalin salah satu gambar kemudian mendekorasikan gambar tersebut dengan menggunakan teknik kolase. Karakter mandiri dan kreatif sudah nampak akan tetapi dibatasi. Sebaiknya siswa diberi kebebasan dalam memilih gambar yang akan didekorasikan dengan menggunakan teknik kolase. Sehingga karakter kreatif dan mandiri pada siswa bisa tampak.

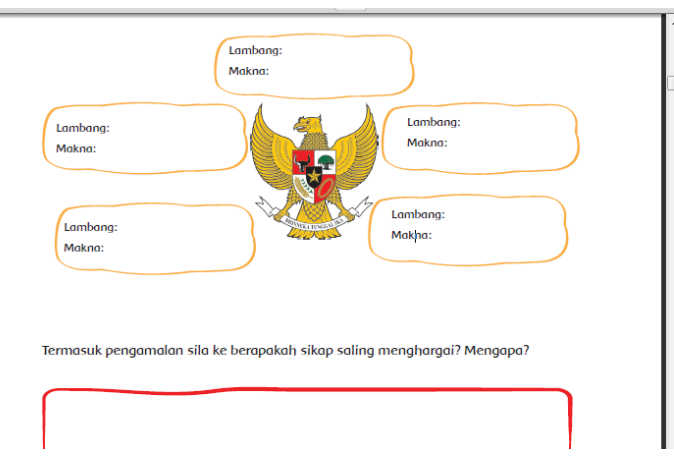

Tidak seluruh nilai karakter yang disampaikan di muka muncul pada subtema 1. Nilai karakter yang paling menonjol pada subtema ini adalah rasa ingin tahu, kreatif, mandiri, dan bersahabat/ komunikatif. Adapun nilai karakter yang belum muncul adalah nilai karakter relegius, disiplin, cinta damai demokratis, semangat kebangsaan, cinta tanah air, menghargai prestasi, cinta damai, peduli lingkungan, dan peduli sosial.

\section{Aspek Pendekatan Scientific dalam Buku Siswa Kelas IV SD}

Salah satu ciri khusus dari Kurikulum 2013 adalah pendekatan yang digunakan. Pendekatan yang digunakan dalam pembelajaran adalah pendekatan ilmiah atau biasa dikenal dengan pendekatan saintifik (scientific approach). Dalam Peraturan Menteri Pendidikan dan Kebudayaan Republik Indonesia Nomor 103 Tahun 2014 Tentang Pembelajaran pada Pendidikan Dasar dan Pendidikan Menengah, dijelaskan bahwa pendekatan scientific/pendekatan berbasis proses keilmuan merupakan pengorganisasian pengalaman belajar dengan urutan logis meliputi proses pembelajaran: 1) mengamati; 2) menanya; 3) mengumpulkan informasi/mencoba; 4) menalar/mengasosiasi; dan 5) mengomunikasikan. Dikarenakan pendekatan saintifik ini merupakan salah satu ciri khusus kurikulum 2013, maka buku tematik kurikulum 2013 harus memuat kelima aspek di atas. Sehingga kelima aspek pendekatan yang digunakan perlu menjadi indikator penting dalam menganalisis kesesuaian materi dengan pendekatan tersebut.

Pada Subtema 1: Aku dan Cita-Citaku halaman 4-5 Kegiatan "Ayo Berkreasi dan Ayo Cari Tahu" adalah kegiatan yang memandu siswa untuk menalar/ mengasosiasi dan mengumpulkan informasi/ mencoba yang diperoleh dari kegiatan menggambar jenis pekerjaan dan melakukan wawancara sudah nampak/sesuai. Namun, tidak nampak kegiatan mengkomunikasikan, hanya menulis kesimpulan dari kegiatan yang telah dilakukan. Sebaiknya siswa diberikan kesempatan untuk mengomunikasikan atau menyampaikan hasil dari tugas yang diberikan di depan kelas.

Kegiatan "Ayo Berkreasi dan Ayo Cari Tahu" pada halaman 7 adalah kegiatan yang memandu siswa untuk menalar/mengasosiasi dan mengumpulkan informasi /mencoba yang diperoleh dari kegiatan menggambar jenis pekerjaan dan melakukan 
wawancara sudah nampak/sesuai. Namun, tidak nampak kegiatan mengkomunikasikan, hanya menulis kesimpulan dari kegiatan yang telah dilakukan. Sebaiknya ditambahkan perintah untuk mengomunikasikan di depan kelas. Sehingga pendekatan scientific mengomunikasikan dapat nampak dalam pembelajaran.

Pada kegiatan "Ayo Ceritakan" halaman 25 siswa diminta untuk menuliskan aturan-aturan dalam melakukan kegiatan dan menuliskan manfaat dari mengikuti aturan-aturan itu, serta akibat jika aturan tersebut tidak dipatuhi. Namun siswa tidak diberi kesempatan untuk membacakan hasil dari yang dikerjakannya. Sehingga pendekatan saintifik mengomunikasikan belum nampak. Sebaiknya ditambahkan perintah untuk mempresentaiskan di depan kelas. Agar muncul M yang ke-5 (mengkomunikasikan).

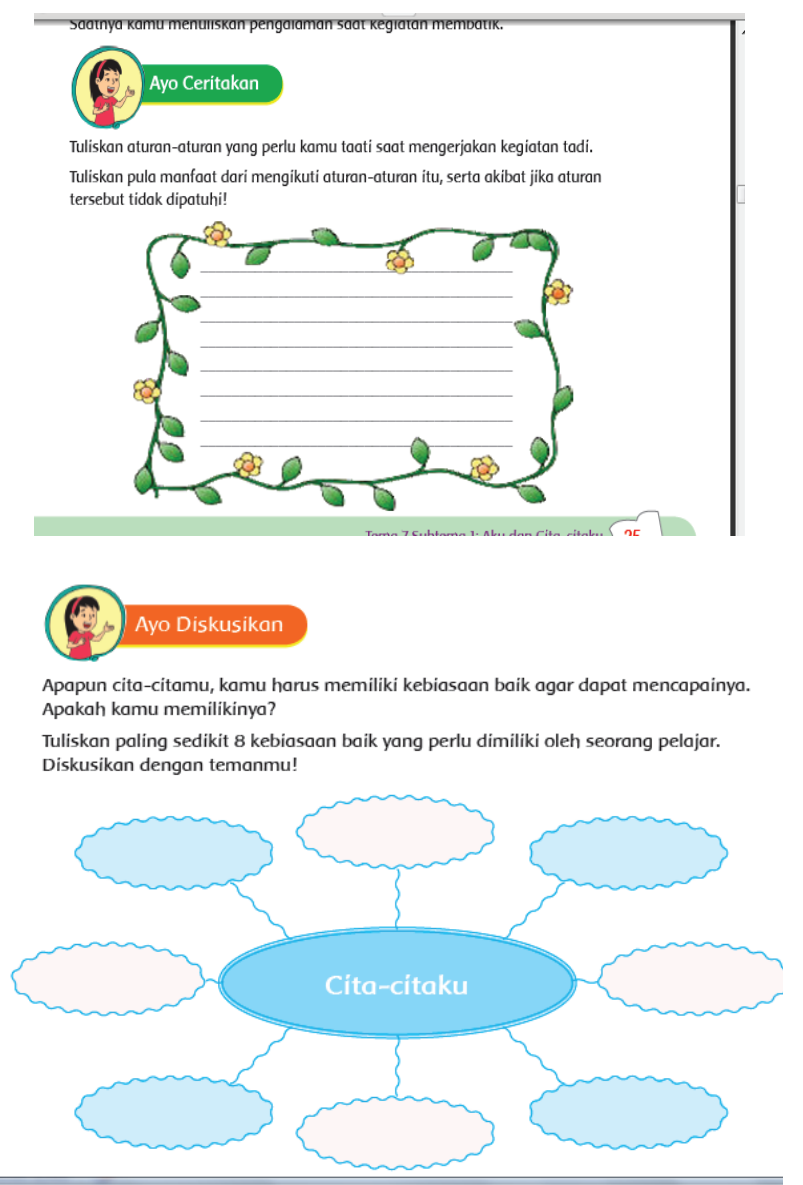

Pada kegiatan "Ayo Diskusikan" pada halaman 30 siswa diminta untuk mendiskusikan (mengumpulkan informasi dan menalar) kebiasaan- kebiasaan baik yangdapat dilakukan dalam mencapai cita-cita. Namun, dari kegiatan tersebut tidak ada perintah untuk siswa menyampaikan hasil diskusinya.
Sehingga pendekatan saintifik mengomunikasikan belum nampak. Sebaiknya siswa diminta untuk mempresentasikan (mengkomunikasikan) hasil diskusi di depan kelas sehingga siswa dapat membandingkan hasil diskusi dari setiap kelompok.

temanmu melakukan pekerjaan yang sama? Apakah setiap orang mempunyai kewajiban untuk mengerjakan tugasnya dengan baik? Tuliskan pengalamanmu dalam kolom berikut!

Pada kegiatan "Ayo Ceritakan" pada halaman 31 siswa diminta untuk menulis pengalamannya dalam menjalankan menyelesaikan tugas dengan baik. Kegiatan ini mendorong siswa untuk mencoba menulis pengalamannya masing- masing. Namun, tidak adakegiatan tindak lanjut darikegiatan tersebut. Pendekatan saintifik yaitu mengomunikasikan belum nampak. Sebaiknya ditambahkan kegiatan siswa saling menceritakan pengalaman masingmasing sehingga siswa dapat berbagi pengalaman. Kegiatan tersebut dapat memunculkan pendekakatan saintifik yaitu mengomunikasikan.

\section{PEMBAHASAN}

\section{Kesesuaian Buku Siswa dengan Pendidikan Karakter dalam Kurikulum 2013}

Pendidikan karakter di SD merupakan salah satu awal dari penanaman karakter pada anak karena pada masa ini anak masih dalam tahap perkembangan. Sebenarnya, semua elemen di masyarakat harus bertanggung jawab dalam mendidik karakter para generasi penerus bangsa. Namun, secara hakiki keluarga tetaplah yang paling utama di dalam upaya pendidikan karakter bagi anak.

Seiring dengan perkembangan zaman yang mengarah pada era globalisasi dan kemajuan teknologi informasi, banyak orang tua sendiri yang mengalami kesulitan dalam melakukan pengawasan karena memiliki rutinitas yang padat. Oleh karena itu, pendidikan karakter juga sangat perlu diberikan di sekolah. Dalam hal ini, guru menjadi ujung tombak bagi pendidikan karakter siswa, karena hampir tiap hari guru langsung berhadapan dengan siswa. Hal ini, sejalan dengan pendapat Milson \& 
Mehling (2002) yang mengemukakan bahwa guru merupakan faktor penting dalam pengembangan karakter anak di masa muda. Sehingga guru harus mampu memberikan contoh berperilaku yang baik dalam sekolah.

Selain guru harus mampu memberikan contoh yangbaikdalamberperilaku, hal-halyangdisampaikan guru kepada siswa, termasuk di dalamnya materi pelajaran, hendaknya memuat pendidikan karakter. Hal ini, mendukung pendapat Judiani, (2010) yang menyatakan bahwa pendidikan di Indonesia selama ini masih terfokus pada aspek-aspek kognitif atau akademik, sedangkan aspek softskills atau nonakademik masih kurang mendapatkan perhatian sehingga diperlukan kurikulum yang memasukkan pendidikan karakter.

Terdapat 18 nilai karakter dalam Kurikulum 2013 merinci secara ringkas nilai-nilai karakter yang harus ditanamkan kepada siswa di sekolah dasar. Ke-18 karakter tersebut yaitu: (1) religius, (2) jujur, (3) toleransi, (4) disiplin, (5) kerja keras, (6) kreatif, (7) mandiri, (8) demokratis, (9) rasa ingin tahu, (10) semangat kebangsaan, (11) cinta tanah air, (12) menghargai prestasi, (13) bersahabat/komunikatif, (14) cinta damai, (15) gemar membaca, (16) peduli lingkungan, (17) peduli sosial, (18) tanggung jawab.

Seluruh karakter di atas telah muncul dalam Buku Siswa Kelas IV SD yang disusun oleh Kemendikbud berdasarkan Kurikulum 2013. Hanya saja, tidak seluruh karakter tersebut tampil pada tempat (materi) yang tepat, dan sebagian di antaranya disampaikan dalam porsi yang sedikit.

Nilai karakter yang paling banyak dimunculkan dalam Buku Siswa Kelas IV SD adalah rasa ingin tahu, kreatif, mandiri, bersahabat/komunikatif, tanggung jawab, kerja keras, dan peduli sosial. Nilainilai karakter ini muncul terutama pada buku siswa dengan tema-tema yang dekat dengan keseharian anak, seperti Cita-Citaku, Indahnya Kebersamaan, Peduli Makhluk Hidup, Tempat Tinggalku, dan Makanan Sehat Bergizi. Dalam menentukan tema digunakanlah prinsip yaitu (a) sesuai kebutuhan, (b) peristiwa yang terjadi di lingkungan, (c) menarik minat anak, (d) intelegensi seluruh mata pelajaran, (e) mulai dari konsep yang lebih umum, menyeluruh kemudian ke arah yang lebih spesifik sesuai cara mengorganisir pengetahuan (Buchory. 2013:7). Sebagaimana harapan dalam Kurikulum 2013, diharapkan siswa memiliki rasa ingin tahu yang tinggi sehingga secara otomatis mereka menjadi kreatif. Diharapkan pula siswa menjadi pribadi yang tangguh, sehingga karakter tanggung jawab, mandiri, dan kerja keras juga banyak dimunculkan dalam "Buku Siswa Kelas IV SD". Perkembangan kognitif harus diimbangi dengan perkembangan sikap (afektif). Karenanya dalam buku siswa tersebut cukup banyak pula dimunculkan nilai karakter peduli sosial dan bersahabat/komunikatif.

Menurut Papalia, et al, (2009) masa kanakkanak tengah dimulai dari usia 6-11 tahun. Mereka juga memiliki karakteristik mulai gemar berhubungan dengan kelompok sosialnya. Dengan demikian, pemberian nilai karakter peduli sosial dalam porsi besar dalam buku siswa kelas IV SD merupakan langkah tepat. Siswa dapat dengan mudah memperoleh kesempatan mengaplikasikan karakter yang diajarkan dalam buku siswa tersebut ke kehidupan nyata dalam pergaulan sehari-harinya.

Pada usia 11 tahun, anak sudah mampu mendeskripsikan perasaan yang dirasakannya (Papalia, et al, 2009). Pernyataan ini mendukung pemberian porsi yang besar pada nilai karakter bersahabat/ komunikatif dalam buku siswa kelas IV SD. Dengan mengenal emosi positif dan emosi negatif maka siswa akan mengenal perasaan suka dan tidak suka pada orang lain. Dengan demikian, pemberian porsi yang besar pada nilai karakter bersahabat/ komunikatif dalam buku siswa kelas IV SD dinilai sangat tepat. Marzuki (2012) juga menyatakan bahwa pengintegrasian pendidikan karakter dalam pembelajaran dapat dilakukan dengan pemuatan nilai-nilai karakter dalam semua mata pelajaran yang diajarkan di sekolah dan dalam pelaksanaan kegiatan pembelajaran.

Dengan demikian secara garis besar dapat dikatakan bahwa pemberian porsi yang besar pada nilai karakter tanggung jawab, mandiri, kerja keras, peduli sosial, dan bersahabat/komunikatif dalam buku siswa Kelas IV SD merupakan tindakan yang tepat karena memang sesuai dengan psikologi perkembangan anak di usia mereka. Namun, apabila dicermati lebih lanjut pada buku siswa tersebut, di beberapa bagian ditemukan penempatan nilai karakter yang tidak selaras dengan materi yang akan disampaikan kepada siswa.

Nilai-nilai karakter yang muncul dalam buku siswa Kelas IV SD namun dalam porsi sangat terbatas adalah nilai religius, demokratis, semangat kebangsaan, cinta tanah air, toleransi, disiplin, jujur, cinta damai, dan menghargai prestasi. 
Minimnya kemunculan nilai karakter religius, demokratis, semangat kebangsaan, cinta tanah air, dan toleransi dalam buku siswa kelas IV SD terjadi karena memang nilai-nilai tersebut bersifat abstrak. Sebagaimana diketahui, (Piaget dalam Slavin. 2008) dalam mengkategorikan anak usia SD berada pada tahap operasional konkret. Artinya, mereka cenderung lebih mudah memahami dan memaknai segala sesuatu yang bersifat konkret. Nilai karakter lain yang juga tidak banyak dimunculkan dalam buku siswa kelas IV SD adalah jujur, cinta damai, dan menghargai prestasi. Hal ini kurang tepat sebab meski ketiga karakter itu bersifat abstrak namun mudah sekali menerapkan ketiganya dalam dunia anak. Banyak hal dalam aktivitas dan kehidupan anak dapat dikaitkan dengan kejujuran, cinta damai, dan menghargai prestasi. Misalnya, mengakui kesalahan sebagai penanaman nilai karakter jujur, memaafkan teman yang bersalah sebagai penanaman nilai karakter cinta damai, dan memberi selamat kepada teman yang memenangkan suatu perlombaan untuk penanaman karakter menghargai prestasi. Menurut Akbar (2014:148) pembiasaan rutin untuk melakukan kebaikan-kebaikan yang dilakukan di sekolah dapat mengembangkan karakter yang baik. Dengan demikian, kurang tepat kiranya apabila porsi kemunculan karakter jujur, cinta damai, dan menghargai prestasi dalam buku siswa kelas IV SD tidak banyak.

\section{Kesesuaian Buku Siswa dengan Pendekatan Scientific dalam Kurikulum 2013}

Secara umum buku siswa kelas IV SD berlum disajikan dengan berlandaskan pendekatan scientific. Meski dalam pengantar telah ditulis bahwa pendekatan yang digunakan adalah scientific, namun dalam kenyataan pengembangan materi masih belum menerapkan pendekatan scientific secara tepat.

Kurikulum 2013 menekankan pada dimensi pedagogik modern dalam pembelajaran, yaitu menggunakan pendekatan ilmiah. Pendekatan ilmiah (scientific appoach) dalam pembelajaran semua mata pelajaran meliputi mengamati, bertanya, mencoba, menalar, dan menginformasikan. Untuk mata pelajaran, materi, atau situasi tertentu, sangat mungkin pendekatan ilmiah ini tidak selalu tepat diaplikasikan secara prosedural. Pada kondisi seperti ini, tentu saja proses pembelajaran harus tetap menerapkan nilai-nilai atau sifat-sifat ilmiah, serta menghindari nilai-nilai atau sifat-sifat nonilmiah seperti intuisi, akal sehat, prasangka, penemuan melalui coba-coba, dan asal berpikir kritis (Kemendikbud, 2013a).

Berdasarkan analisis yang telah dilakukan, penyajian materi pada Buku Siswa kelas IV belum sepenuhnya memenuhi kriteria dalam pendekatan scientific. Beberapa bagian masih disajikan dengan cara konvensional, yaitu memaparkan materi secara langsung tanpa memberi kesempatan kepada siswa untuk mencoba, menanya, dan menalar. Bahkan, sebagian di antaranya disajikan dalam bentuk paparan yang hanya bisa dibaca oleh siswa, tanpa dapat diamati.

Sebagai contoh, penyampaian materi sudut dalam Buku Siswa kelas IV tema 'Indahnya Kebersamaan' (Kemendikbud, 2013a) di atas dapat dikatergorikan tidak memenuhi kriteria pendekatan scientific. Lima langkah dalam pendekatan scientific adalah mengamati, menanya, mencoba, menalar, dan mengomunikasikan tidak diwujudkan dalam penyampaian materi tersebut. Petikan Buku Siswa di atas menunjukkan bahwa tidak ada upaya mengamati karena siswa langsung ditunjukkan bentu-bentuk sudut lancip. Seharusnya penulis memberikan ilustrasi berbagai benda di sekitar siswa yang mengindikasikan adanya sudut lancip di dalamnya dan siswa diminta mengamatinya terlebih dulu. Misalnya, tangkai dan cabang pohon atau penjepit kue, atau paruh burung ketika membuka, atau bukti-bukti lain dari kehidupan di sekitar siswa yang menunjukkan bentuk sudut lancip. Pada petikan di atas siswa juga tidak diberi kesempatan menanya. Pertanyaan yang diberikan dalam buku pun terbatas pada pertanyaan apersepsi ("Ingatkah kamu apa yang dimaksud dengan sudut?") yang ditujukan untuk mengingatkan siswa pada pembelajaran sebelumnya. Tidak ditemukan adanya upaya menggali pengetahuan siswa sehingga siswa memunculkan pertanyaan kritis terkait sesuatu yang diamatinya. Siswa juga tidak diberi kesempatan mencoba dan menalar berbagai hal terkait sudut sebab dalam buku tersebut penulis langsung menyebutkan definisi sudut dan jenis-jensi sudut beserta penjelasannya. Seharusnya siswa diberi kesempatan memikirkan dan menemukan terlebih dulu berbagai hal terkait sudut. Semestinya tidak perlu ada paparan eksplanatif terkait materi ajar yang harus dikuasai siswa. 
Kemendikbud (2013a) mendefinisikan pendekatan scientific sebagai perpaduan antara proses pembelajaran yang semula berfokus pada eksplorasi, elaborasi, dan konfirmasi dilengkapi dengan mengamati, menanya, menalar, mencoba, dan mengkomunikasikan. Berdasarkan batasan tentang pendekatan scientific tersebut dapat diketahui bahwa petikan materi tentang sudut dalam Buku Siswa kelas IV tema 'Indahnya Kebersamaan'di atas mengindikasikan terlanggarnya empat kriteria pendekatan scientific, yaitu siswa tidak diberi kesempatan untuk mengamati, siswa tidak diberi kesempatan untuk menanya, siswa tidak diberi kesempatan untuk menalar, dan siswa tidak diberi kesempatan untuk mencoba.

Mengamati mengutamakan kebermaknaan proses pembelajaran (meaningfull learning). Metode ini memiliki keunggulan tertentu, seperti menyajikan media objek secara nyata, peserta didik senang dan tertantang, dan mudah pelaksanaannya. Tentu saja kegiatan mengamati dalam rangka pembelajaran ini biasanya memerlukan waktu persiapan yang lama dan matang, biaya dan tenaga relatif banyak, dan jika tidak terkendali akan mengaburkan makna serta tujuan pembelajaran. Metode mengamati sangat bermanfaat bagi pemenuhan rasa ingin tahu peserta didik, sehingga proses pembelajaran memiliki kebermaknaan yang tinggi. Dengan observasi peserta didik menemukan fakta bahwa ada hubungan antara objek yang dianalisis dengan materi pembelajaran yang digunakan oleh guru.

Bertanya dimaksudkan untuk membangkitkan rasa ingin tahu, minat, dan perhatian peserta didik tentang suatu tema atau topik pembelajaran. Selainitu, bertanya dapat mendorong dan menginspirasi siswa untuk aktif belajar, serta mengembangkan pertanyaan dari dan untuk dirinya sendiri. Bertanya juga berfungsi menstrukturkan tugas-tugas dan memberikan kesempatan kepada siswa untuk menunjukkan sikap, keterampilan, dan pemahamannya atas substansi pembelajaran yang diberikan. Mencoba merupakan aplikasi dari metode eksperimen. Mencoba ini untuk mengembangkan berbagai ranah tujuan belajar, yaitu sikap, keterampilan, dan pengetahuan. Untuk memperoleh hasil belajar yang nyata atau otentik, siswa mencoba atau melakukan percobaan, terutama untuk materi atau substansi yang sesuai. Dalam hal ini siswa pun harus memiliki keterampilan proses untuk mengembangkan pengetahuan tentang alam sekitar, serta mampu menggunakan metode ilmiah dan bersikap ilmiah untuk memecahkan masalahmasalah yang dihadapinya sehari-hari.

Istilah "menalar" dalam kerangka proses pembelajaran dengan pendekatan ilmiah digunakan dalam Kurikulum 2013 untuk menggambarkan bahwa guru dan siswa merupakan pelaku aktif. Titik tekannya tentu dalam banyak hal dan situasi siswa harus lebih aktif daripada guru. Penalaran adalah proses berfikir yang logis dan sistematis atas fakta-kata empiris yang dapat diobservasi untuk memperoleh simpulan berupa pengetahuan. Menalar dapat dilakukan dengan dua cara, yaitu penalaran induktif dan penalaran deduktif. Penalaran induktif merupakan cara menalar dengan menarik simpulan dari fenomena atau atribut-atribut khusus untuk halhal yang bersifat umum. Kegiatan menalar secara induktif lebih banyak berpijak pada observasi inderawi atau pengalaman empirik. Pola penalaran deduktif dikenal dengan pola silogisme. Cara kerja menalar secara deduktif adalah menerapkan halhal yang umum terlebih dahulu untuk kemudian dihubungkan ke dalam bagian-bagiannya yang khusus.

Lebih baik lagi kalau pengembangan Buku Siswa selain menerapkan pendekatan scientific juga mengaplikasikan pendekatan PAKEM. Dengan demikian, pembelajaran dapat berlangsung secara lebih menyenangkan Ruminiati (2014). Hal ini sesuai dengan pendapat Paut (2016) bahwa manfaat yang diperoleh guru dalam menggunakan pendekatan scientific dalam proses pembelajaran yaitu dengan adanya pendekatan scientific, siswa menjadi lebih aktif, kreatif, pembelajaran semakin lebih menyenangkan, siswa dapat berpikir lebih ilmiah dan karakter siswa semakin dibentuk.

\section{SIMPULAN DAN SARAN}

\section{Simpulan}

Berdasarkan hasil analisis data dan pembahasan di muka, dapat ditarik kesimpulan bahwa nilai karakter yang paling banyak dimunculkan dalam buku siswa Kelas IV SD adalah rasa ingin tahu, kreatif, mandiri, bersahabat/komunikatif, tanggung jawab, kerja keras, dan peduli sosial. Nilai-nilai karakter ini muncul terutama pada buku siswa dengan tema-tema yang dekat dengan keseharian anak, seperti Cita-Citaku, Indahnya Kebersamaan, Peduli Makhluk Hidup, Tempat Tinggalku, dan Makanan Sehat Bergizi. Karakter-karakter tersebut 
banyak muncul karena keberadaannya memang dekat dengan keseharian siswa, dan secara psikologis memang sesuai dengan karakteristik perkembangan anak usia setara siswa kelas IV SD. Hanya saja, sering terjadi nilai-nilai karakter tersebut muncul pada konteks yang tidak tepat karena kemunculannya tidak koheren dengan materi yang ditumpanginya.

Secara umum buku siswa kelas IV SD belum disajikan dengan berlandaskan pendekatan scientific. Meski dalam pengantar telah ditulis bahwa pendekatan yang digunakan adalah scientific, namun dalam kenyataan pengembangan materi masih belum menerapkan pendekatan scientific secara tepat. Beberapa bagian masih disajikan dengan cara konvensional, yaitu memaparkan materi secara langsung tanpa memberi kesempatan kepada siswa untuk mencoba, menanya, dan menalar. Bahkan, sebagian di antaranya disajikan dalam bentuk paparan yang hanya bisa dibaca oleh siswa, tanpa dapat diamati.

\section{Saran}

Berdasarkan hasil penelitian di muka, disarankan nilai karakter yang akan ditanamkan kepada siswa hendaknya dipilih yang memang dekat dengan kehidupan siswa dan sesuai dengan psikologi perkembangan anak seusia mereka. Nilai- nilai karakter yang demikian akan mudah dipahami dan dimaknai oleh siswa sehingga peluang keberhasilannya dalam pembelajaran menjadi lebih besar.

Pada penyusunan buku siswa edisi baru atau edisi revisi, sebaiknya dipertimbangkan betul keberadaan pendekatan scientific dalam Kurikulum 2013. Hendaknya materi disajikan dengan memperhatikan langkah-langkah pembelajaran yang mengondisikan siswa untuk memiliki kesempatan dalam mengamati, menanya, mencoba, menalar, dan kemudian mengkomunikasikan. Dengan demikian, buku siswa secara tidak langsung telah menggambarkan bagaimana langkah penyampaiannya kepada siswa dalam pembelajaran.

\section{DAFTAR RUJUKAN}

Akbar, S. 2014. Model Pendidikan Karakter yang Baik (Studi Lintas Situs Bests Practices) Pendidikan Karakter di SD. Jurnal Sekolah Dasar. 24(2):139-151.

Benninga, Berkowitz, Kuehn, \& Smith. 2003. The Relationship Of Character Education
Implementation and Academic Achievement In Elementary Schools. Jurnal of Research In Character Education. 19-32.

Buchory, M.S. 2013. Pengembangan Model Pembelajaran Tematik Kelas Awal Sekolah Dasar. Jurnal Sekolah Dasar. 22(1):1-8.

Depdiknas. 2003. UU Nomer 20 Tahun 2003 Tentang Pendidikan Nasional. Jakarta: Kemendiknas.

Judiani, S. 2010. Implementasi Pendidikan Karakter di Sekolah Dasar Melalui Penguatan Pelaksanaan Kurikulum. Jurnal Pendidikan dan Kebudayaan, 16. (Online). (http:// jurnal dikbud. kemdikbud.go.id/index.php/jpnk/article/ viewFile/519/358), diakses 5 Maret 2016.

Kemendikbud, 2013b. Salinan Lampiran Peraturan Menteri Pendidikan dan Kebudayaan Nomor 54 Tahun 2013 tentang Standar Kompetensi Lulusan Pendidikan Dasar dan Menengah. Jakarta: Kemendikbud.

Kemendikbud. 2013a. Materi Pelatihan Guru: Implementasi Kurikulum 2013. Jakarta: Kemendikbud. Papalia Olds \&Feldman. 2007. Karakteristik Masa Anak-Anak. Jakarta: Erlangga.

Marzuki. 2012. Pengintegrasian Pendidikan Karakter dalam Pembelajaran di Sekolah. Jurnal Pendidikan Karakter II (02). (Online), (http:/journal.uny.ac.id/index.php/jpka/article/ view/12057), diakses 21 April 2015.

Milson \& Mehling. 2002. Elementary School Teachers' Sense of Efficacy for Character Education. Journal of Educational Research. 96(1):324-335.

Papalia D.E., Olds, S.W, \& Feldman, R.D. 2009. Human Development (Perkembangan Manusia edisi 10 buku 2). (Penerjemah. Brian Marwensdy). Jakarta: Salemba Humanika.

Paut. 2016. Penerapan Pendekatan Scientific pada Siswa Kelas IV di SD Pujokusuman 1 Yogyakarta. Jurnal Pendidikan Guru Sekolah Dasar. 6 (5): 21-29.

Sari, I. P \& Syamsi, K. 2015. Pengembangan Buku Pembelajaran Tematik-Integratif Berbasis Nilai Karakter Disiplin dan Tanggung Jawab di Sekolah Dasar. Jurnal Prima Edukasi, 3(1). (Online).

Ruminiati 2014. Pendekatan Scientific dan Pendekatan Pakem. Makalah Disajikan Pada Seminar Nasional, Direktorat Pendidikan Sekolah Dasar, Surabaya, 30 Juli - 3 Agustus 2014. 